\title{
The Role of the Department Head or Chairman: Discipline, Sex and Nationality as Factors Influencing Faculty Opinion
}

\author{
ROY E.L. WATSON*
}

\begin{abstract}
The influence of academic discipline, sex and nationality upon one's definiton of the role of the head or chairman of a university department was studied by means of a questionnaire administered to members of the Faculty of Arts and Science of the University of Victoria. Discipline was found to be of overriding importance. Social scientists; unlike either Natural Scientists or Humanists, rejected leadership while favouring the roles of coordinator and, to a lesser degree, of representative. Women in the Humanities and Natural Sciences were more likely to expect leadership than were their male colleagues. The nationality of the respondents, however, did not appear to influence their expectations of the department head or chairman.

\section{RÉSUMÉ}

$L$ 'influence du domaine académique, du seze et de la nationalité sur la définition qu l'on a du rôle du chef ou du président du département a fait l'objet d'un questionnaire rempli par les membres du corps enseignant de la Faculté des Lettres et des Sciences humaines de l'Université de Victoria. Le domaine s'est avér-e d'importance capitale. Des spécialistes en sciences sociales, différents de ceux en sciences naturelles ou en lettres, rejettent le concept de chef tout en favorisant le rôle de coordonnateur et, jusqu'à un degré moindre, de représentant. Les femmes en lttres et en sciences naturelles s'attendaient davantage à travailler sous un chef que leurs collègues masculins. La nationalité des répondants n'a pas influenceé, paraitt-il, ce que l'on attendait d'un chef ou d'un président de département.
\end{abstract}

Through the 1960's, university governance increasingly attracted the interest of academics both as an issue of local campus politics and as an area of scholarly research. Student activism, the expanding administrative bureaucracy which accompanied the universities'

*Department of Sociology, University of Victoria. 
rapid growth, the application of the computer to internal record-keeping and control (Rourke and Brooks, 1966) all combined to generate among faculty a broad movement directed at reaffirming faculty control over academic decision-making (Bell, 1970:7-8; Eustace, 1959:51). In Canada, the need to reform the structure and procedures of university government was sufficiently evident by 1962 that the Association of Universities and Colleges of Canada and the Canadian Association of University Teachers agreed to jointly sponsor a Commission to study and to make recommendations (CAUT/AUCC, 1966). In turn, the visits of the Commission to campuses across the country and its subsequent Report in 1966 gave a fresh impetus to the drive to liberalize administrative procedures. Like the academic literature which had begun to appear at about the same time in the United States, however, the Commission's recommendations focussed upon the higher levels of university administration, upon the governing Boards and Senates and the offices of President and Dean. ${ }^{1}$ The internal administration of departments received much less attention. ${ }^{2}$ Yet, because most decisions which impinge directly upon the work and careers of individual faculty originate within departments (Dressel et al., 1970:6), the issue of how and by whom such decisions are to be made assumes particular salience and especially to those at junior ranks.

The ideal administration of a group of scholars or scientists, such as constitute a university department, has been described as the collegium or company of equals (Barber, 1952:144; Parsons and Platt, 1967; Baldridge, 1971:5-6). Under certain conditions, the internal government of prestigious departments in major universities appears to approximate this, at least insofar as the senior, tenured members are concerned (Ladd and Lipset, 1973:3; Anderson, 1963:10-14). But few departments enjoy such status and, in the circumstances of rapid growth which prevailed in the sixties, the senior members in many departments found themselves outnumbered by junior colleagues rapidly being added to meet the pressing demands for undergraduate instruction. To these new recruits, untenured and often still struggling to complete advanced degrees, practices which excluded them from the decision-making process by retaining control in the hands of the department head or chairman and a coterie of his senior colleagues were not acceptable and they were likely to be challenged (CAUT/AUCC, 1966:47). Thus, the movement to reaffirm faculty control contained as a strong, and sometimes major, theme, the demand that decision-making be democratized to include the participation of junior staff (Hirabayashi, 1970). Such democratization implied a fundamental redefinition of the role of the office of the departmental administrator as traditionally defined (Blackwell, 1966:38), a redefinition sometimes symbolized by a change in its title from "Head" to "Chairman."

The demand for a democratized administration provoked bitter debate on a number of campuses (CAUT/AUCC, 1966:34), a debate in which members of different departments and even of the same department were to be found on opposing sides. While, as suggested, academic rank or experience is frequently adduced to explain the differing views held on this issue, this does not appear to be the only or most important explanation. The process of socialization which is involved in advanced training, whether in the professions or in academic disciplines, has been shown to instil differing values and political outlooks among those in different fields (Blackburn and Lidquist, 1971; Spaulding and Turner, 1968). One would expect such values to be expressed in the stands taken by academics on the highly salient issue of departmental administration. Social scientists, in particular, would be expected to strongly support the adoption of more liberal procedures. 
21 The Role of the Department Head or Chairman

Insofar as Candian universities are concerned, however, the national backgrounds of staff have also to be considered. The rapid growth of the universities in the sixties did not affect all disciplines to the same degree. Some grew much more rapidly than others and had, consequently, to recruit more staff. In certain disciplines, notably the natural sciences, a supply of Canadian trained personnel was well developed. In the social science, however, not only was expansion extremely rapid but, due to an earlier neglect of graduate training in these disciplines, few Candian-trained personnel were available and universities were compelled to turn to other sources, notably the United States, in their search for staff (Clark, S.D., 1973:208). Lipset, among others, has suggested that "the United States is more achievement-oriented, universalistic, egalitarian and self-oriented than Canada" (1971:24). If this difference in values finds expression within the universities, a pattern of departmental administration embodying hierarchy and elitist values which is acceptable to Canadians might be found to be most uncongenial by recently recruited American scholars and they could be expected to work for change toward a more egalitarian and participative system (Clark, S.D., 1973:207). In the light of the importance which has subsequently been attached to the nationality of professors in Canada (Mathews and Steele, 1971; Symons, 1975), it is interesting to enquire to what degree the earlier support of faculty for democratization of university administration may have reflected such "national" rather than, or in addition to, disciplinary values and/or such personal attributes as the stage of career.

\section{The Role of the Head/Chairman}

The position of the departmental academic administrator has been compared to that of a foreman in industry (Brann, 1972:5). At the lowest rung of the university's administrative structure, the incumbent may experience severe cross pressures especially if departmental colleagues and higher administrators hold different expectations of the office ( $c f$. Etzioni, 1964: 82). This appears to have been increasingly the case through the sixties in certain disciplines, perhaps most notably in Sociology. ${ }^{3}$ One result was that even greater difficulty was experienced in recruiting able people to what was perceived to be "a conspicuously unrewarding role" (DeFleur, 1970:5). Responding to this crisis in the discipline, the President of the Pacific Sociological Association in 1969 had invited four chairmen from as many universities each "to prepare an independent analysis of the leadership role and to comment on some of its more important problems" for presentation to a plenary session of the Association. ${ }^{4}$ It is significant that neither the President nor any of the invited panelists appears to have questioned that the key role of a chairman was that embodying academic leadership ( $c f$. Blackwell, 1966:38, Ahman, 1972). Yet, the unrewarding experience of incumbents who attempted to implement that role, to which each of the panelists testified in his remarks, strongly suggests that their colleagues did not share this definition of the chairman's role. Was this unique to Sociologists or might members of other disciplines also reject leadership as the primary role?

\section{Method}

An attempt to identify factors associated with support or non-support of the movement to democratize departmental administration at one Canadian university was made by 
means of a questionnaire distributed to full-time faculty in Arts and Science at the University of Victoria in the summer and fall of 1970. Of a total of 314 members of this faculty, 234 completed useable questionnaires, a participation rate of $74.5 \% .^{5}$ Victoria cannot be described as fully representative of Anglophone Canadian universities but, like other institutions, it had experienced a period of rapid growth during the late fifties and sixties $^{6}$ which had produced a faculty containing many recent recruits drawn from a wide range of Canadian and foreign universities and with characteristic imbalances in national origin and in experiences among the members of different departments. Moreover, the issue of the role of the department head or chairman was particularly salient because the faculty had just completed a prolonged debate leading up to the adoption of a new Tenure Document. However, at the time data was being collected, the campus was again quiescent and thus provided a convenient locale in which to investigate factors influencing individual opinion.

Victoria respondents were asked to rank order five different roles of the Department Head or Chairman in terms of importance. These roles were identified as follows:

Intellectual Leader: "He should define the academic goals of his department and devise programmes to achieve these."

Coordinator: "He should coordinate the work of . . colleagues and facilitate their productivity by relieving them of administrative duties."

Representative: "He should represent his department to other officers of the university, committees, etc."

Resources Mobilizer: "He should know about and have access to resources; . . . assist colleagues in obtaining the resources they require, particularly from sources outside the University."

Personnel Administrator: "[he should] assess the individuals in his department, their contributions and potentialities."

\section{Finding}

As may be seen in Table I, the most common first choice of faculty was the Coordinator role $(38.5 \%)$. The role of Leader was the first choice of $30.8 \%$, and Representative of $20.5 \%$. If account is taken of all choices to arrive at a weighted index of the importance assigned to each, however, the role of Leader slips to third position behind those of Coordinator and Representative. The remaining roles, those of Resource Mobilizer and Personnel Administrator, ranked much lower and will not be considered further in this paper.

The respondents' expectations of the department's academic administrator were reflected in the title preferred for the office and the terms under which respondents believed its incumbent should be appointed. Those selecting Intellectual Leader as the most important role were significantly more likely to favour the title "Head", while those selecting Coordinator and Representative both strongly favoured "Chairman" (see Table II). Most repondents (69\%) favoured a system of renewable appointments of four or five years duration for the departmental administrator. Of those selecting Leader, however $77 \%$ approved of renewable appointments and a further $14 \%$ believed that appointment should be for an indefinite term "at the pleasure of the Board." Fewer of the respondents selecting the Coordinator or Representative roles favoured renewable appointments ( $62.5 \%$ and $68.9 \%$ respectively) and a significant number in 
23 The Role of the Department Head or Chairman

TABLE I

THE IMPORTANCE OF THE HEAD/CHAIRMAN'S ROLES

\begin{tabular}{|c|c|c|c|c|c|c|c|c|c|c|c|c|}
\hline \multirow{3}{*}{ Rank Assigned } & \multicolumn{12}{|c|}{ Roles } \\
\hline & \multicolumn{2}{|c|}{ Leader } & \multicolumn{2}{|c|}{ Coordinator } & \multicolumn{2}{|c|}{ Representative } & \multicolumn{2}{|c|}{$\begin{array}{l}\text { Resource } \\
\text { Mobilizer }\end{array}$} & \multicolumn{2}{|c|}{$\begin{array}{c}\text { Personne } 1 \\
\text { Administrator }\end{array}$} & \multicolumn{2}{|c|}{ A11 } \\
\hline & $\mathrm{n}$ & $\%$ & $\mathrm{n}$ & $\%$ & $\mathrm{n}$ & $\%$ & $\mathrm{n}$ & $\%$ & n & $\%$ & $\mathrm{n}$ & $\%$ \\
\hline $\begin{array}{l}\text { lst } \\
2 \mathrm{nd} \\
3 \mathrm{rd} \\
4 \mathrm{th} \\
5 \mathrm{th}\end{array}$ & $\begin{array}{l}72 \\
29 \\
24 \\
37 \\
49 \\
\end{array}$ & $\begin{array}{l}30.8 \\
13.5 \\
11.5 \\
18.5 \\
25.1\end{array}$ & $\begin{array}{l}30 \\
55 \\
36 \\
20 \\
15 \\
\end{array}$ & $\begin{array}{r}38.5 \\
25.6 \\
17.3 \\
10.0 \\
7.7\end{array}$ & $\begin{array}{r}48 \\
68 \\
46 \\
35 \\
13 \\
\end{array}$ & $\begin{array}{r}20.5 \\
31.6 \\
22.1 \\
17.5 \\
6.7\end{array}$ & $\begin{array}{r}7 \\
35 \\
68 \\
47 \\
51 \\
\end{array}$ & $\begin{array}{r}3.0 \\
16.3 \\
32.7 \\
23.5 \\
26.2\end{array}$ & $\begin{array}{l}17 \\
28 \\
34 \\
61 \\
67 \\
\end{array}$ & $\begin{array}{r}7.3 \\
13.0 \\
16.3 \\
30.5 \\
34.4\end{array}$ & $\begin{array}{l}234 \\
215 \\
208 \\
200 \\
195\end{array}$ & $\begin{array}{r}100.1 \\
100.0 \\
99.9 \\
100.0 \\
100.1\end{array}$ \\
\hline & 211 & & 216 & & 210 & & 208 & & 207 & & & \\
\hline No Response & 24 & & 19 & & 25 & & 27 & & 28 & & & \\
\hline $\begin{array}{l}\text { Average Rank* } \\
\text { * } \\
\text { * rark }=\frac{\text { tatal }}{}\end{array}$ & 2.8 & $\frac{\mu}{\operatorname{ctan} t}$ & 2.1 & & 2.5 & & 3.5 & & 3.6 & & & \\
\hline
\end{tabular}

TABLE II

THE PREFERRED TITLE FOR DEPARTMENTAL ADMINISTRATOR BY ROLE SELECTED AS MOST IMPORTANT

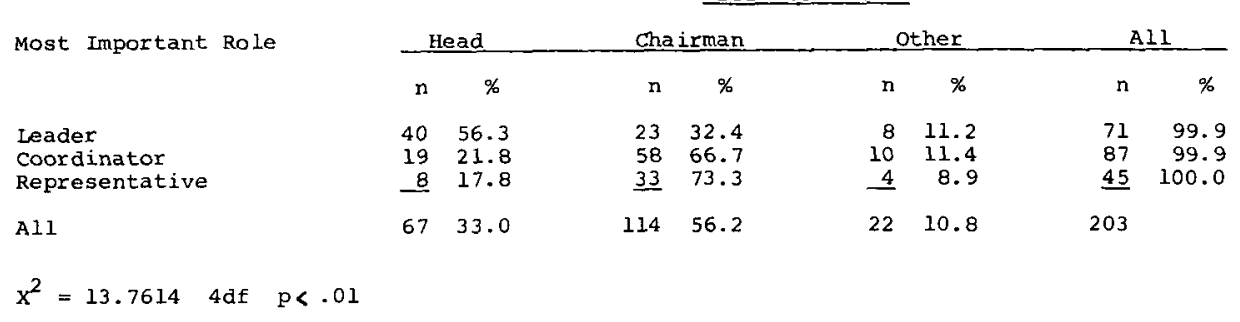

each case (27.3\% and $26.7 \%$ ) preferred either a system of non-renewable appointment or of rotating the office for short terms among the members of a department. Asked whether, once appointed, the Head or Chairman "should be left free to [administer] without being made subject to a lot of democratic checks, "most respondents (63.7\%) disagreed with the suggestion. Those selecting the role of Leader, however, were more likely to approve (38.2\%) and least likely to disagree strongly (16.2\%). Of those selecting the Representative role only $17.4 \%$ approved while $45.7 \%$ expressed strong disapproval. Those selecting the Coordinator role were in an intermediate position, $20.7 \%$ approved of the statement while $25.3 \%$ disapproved strongly.

The selection made of the most important role of the Head/Chairman seems, therefore, to have reflected a more general attitude toward the office and the powers of its incumbent. Those selecting Leader were more likely to look for a "Head" who would remain in the office for a relatively long period during which time he would be reasonably free to give direction to his department. Those selecting Representative typically wanted a "Chairman" who, if he proved satisfactorily, might be reappointed but who, during his term of office, would operate within a democratic framework. Those selecting Coordinator occupied a position somewhere between the Leader and Representative groups. 
SELECTION OF MOST IMPORTANT ROLE BY DISCIPLINE GROUP

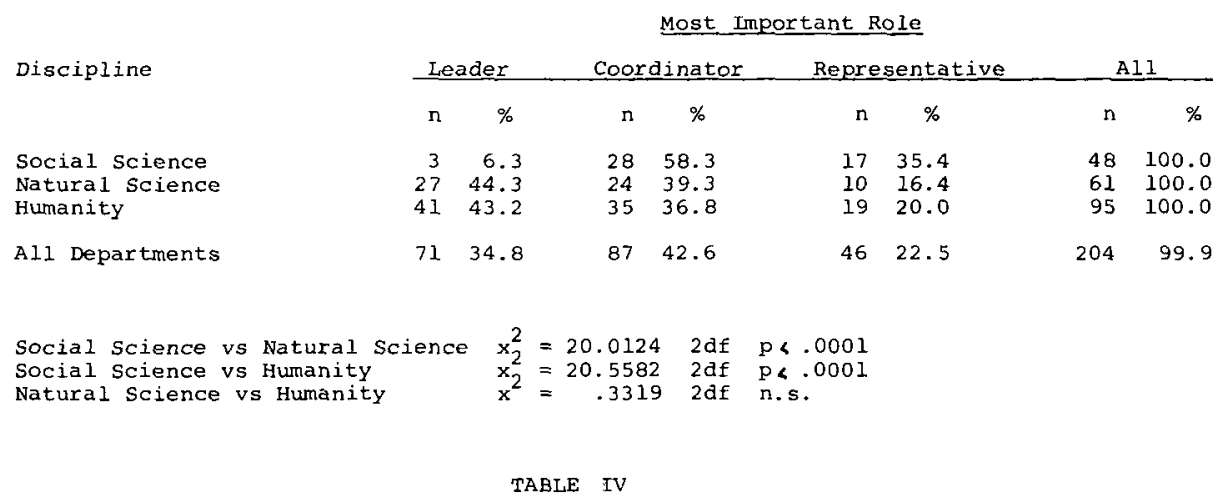

CHOICE OF ROLE BY DISCIPLINE CONTROLLING FOR SEX OF RESPONDENT

Choice of Role

\section{Leader}

Coordinator

Representative

A.1
Males

Discipline
$\begin{gathered}\text { Social } \\ \text { Science }\end{gathered}$ Science Humanities

$\begin{array}{llllll}\mathrm{n} & \% & \mathrm{n} & \% & \mathrm{n} & \%\end{array}$

$\begin{array}{llllll}3 & 6.5 & 21 & 41.2 & 28 & 36.4\end{array}$

$\begin{array}{llllll}27 & 58.7 & 22 & 43.1 & 30 & 39.0\end{array}$

$\begin{array}{llllll}16 & 34.8 & -8 & 15.7 & 19 & 24.7\end{array}$

$\begin{array}{lllll}46 & 100.0 \quad 51 \quad 100.0 \quad 77 & 100.0\end{array}$

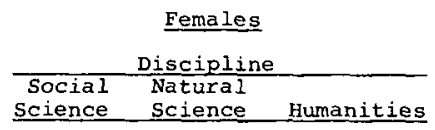

$\begin{array}{llllll}\mathrm{n} & \% & \mathrm{n} & \% & \mathrm{n} & \%\end{array}$

$\begin{array}{lllll}- & 6 & 60.0 & 13 & 72.2\end{array}$

$\begin{array}{lrrrrr}1 & 50.0 & 2 & 20.0 & 8 & 27.8\end{array}$

$\underline{1} \underline{50.0} \underline{2} \underline{20.0}=$

$2100.0 \quad 10100.0 \quad 21100.0$

$\begin{array}{lllll}\text { Males: } & \text { Social Science vs Natural Science } & x_{2}^{2}=16.4594 & 2 d f & p<.001 \\ \text { Social Science vs Humanity } & x_{2}=13.6189 & 2 d f & p<.001 \\ & \text { Natural Sciences vs Humanity } & x^{2}=1.1957 & 2 d f \text { n.s. }\end{array}$

\section{Factors Influencing the Choice of Role}

\section{Discipline}

Review of the literature and personal observation led to the expectation that, in the selection of the most important role of the Head or Chairman, one's discipline would exert a strong influence. To test whether or not this was true, respondents were grouped into Social Science, Natural Science and Humanities and their choices tabulated. ${ }^{7}$ As expected, the Social Science respondents differed significantly from both Natural Science and Humanities (Table III). Social Scientists chose the role of Coordinator most commonly (58.3\%) and Representative next (34.4\%) with only $6 \%$ identifying Leadership as the most important role. For both Natural Science and Humanities respondents, Leader was the most frequently chosen and Representative the least. The close agreement of these groups, however, was not expected. The Humanities had been hypothesized to occupy a middle ground between Social and Natural Science in their attitude toward the Head or Chairman. This suggested that other personal attributes of respondents might be interfering with the 
influence of their disciplines, ${ }^{8}$ perhaps accentuating the contrast with Social Scientists while masking differences between Natural Scientists and Humanists. Three such factors were investigated: the teaching experience of respondents, their sex, and their nationality.

Comparison of the three discipline groups in terms of the teaching experience of their members revealed some slight tendency for Humanists to be more and Social Scientists less experienced but the differences did not reach the level of significance. Moreover, experience was not significant in the choice of role. The sex of respondents, however, did appear to be a significant factor. Not only did the Social Science respondents include significantly fewer women and the Humanities more but women were far more likely to choose the role of Leader. Nevertheless, when discipline groups are compared, controlling for the sex of respondents, the difference in the choices between Social Scientists and either Natural Scientists or Humanists, for males, remains highly significant (Table IV). The smaller number of female respondents presents the same statistical test but it is apparent that the two female social scientists, like their male conterparts, reject leadership as the principal role of the chairman and, in this respect, contrast markedly to females in either of the other discipline groups.

\section{Nationality}

The questionnaire contained two items related to the nationality of respondents. The first of these, the nation within which the first degree was completed, has been shown to be a reliable indicator of citizenship for certain social scientists and, presumably, is so also for other academics (Lambert and Curtis, 1973:69). The second, the national origin of the highest degree, identifies the country within which respondents experienced socialization into their disciplines at a professional level. On neither basis did the choices of Canadians differ significantly from those made by American respondents.

This negative finding with respect to the influence of nationality had not been expected. Graduate students are initiated into the inner workings of a department in a way not commonly experienced by undergraduates and if, as is widely believed, the norms regulating how departments conduct their internal affairs differ as between the universities of different countries, one would expect graduates from different countries to come to hold differing expectations with respect to departmental decision-making. To explore further the influence of nationality, the role choices of respondents were compared, controlling first for discipline and then for nation of highest degree (Table V). Once again, Canadiantrained Social Scientists, Natural Scientists and Humanists did not differ significantly from their American-trained colleagues. The influence of discipline upon choices, however, was maintained. Canadian-trained Social Scientists still differed significantly from Natural Scientists and Humanists as, indeed, American-trained Social Scientists also differed from Natural Scientists and Humanists trained in the United States.

\section{Summary and Conclusions}

Analysis of the responses of faculty at the University of Victoria, when asked to identify the most important role of a departmental head or chairman, lends strong support to the significance of one's discipline in influencing the expectations which will be directed at this office's incumbent. Female respondents other than those in the Social Sciences were 
THE CHOICE OF ROLE BY DISCIPLINE, CONTROLLING FOR NATION OF HIGHEST DEGREE

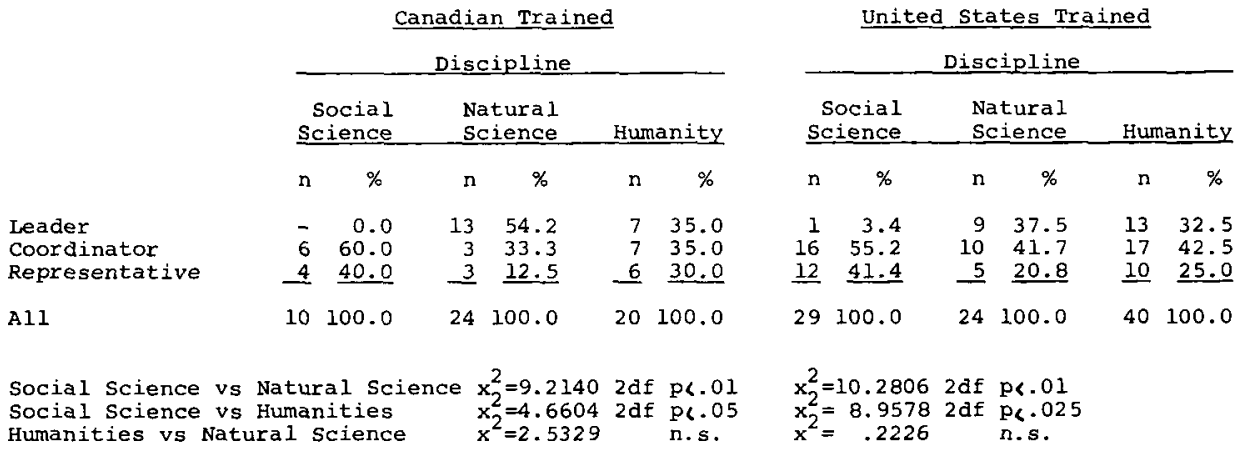

more likely than their male colleagues to expect a leadership role of the department head or chairman but the sex of the respondent did not outweigh the influence of one's discipline. Male social scientists differed significantly from both Natural Scientists and Humanists in their perception of the role. Contary to expectations based on the literature describing the national cultures of Canada and the United States, it was found that Canadian and American trained Social Scientists, as was also true of Natural Scientists and Humanists trained in these two countries, agreed closely in their perception of the Chairman's role even while Social Scientists, wherever trained, contrasted to respondents from other disciplinary areas.

While it is undoubtedly hazardous to attempt to generalize from one campus to all Anglophone universities in Canada, the findings of this study suggest that the active part played by Social Scientists in the campaign to reform administrative practices owed relatively little to the influx of Americans and of the American-trained to staff the expanding Social Science departments. Social Scientists, unlike the Natural Scientists or Humanists, did not look to their Chairman for leadership. However, they often found themselves in departments which had been structured by the expectations of members of those other, longer established, disciplines and they worked to change these structures. As was noted earlier, the conflicting expectation directed at the Chairmen of departments, most notably of Sociology, made the position singularly unattractive. Insofar as administrative structure and practices originating beyond a department affected unfavourably the relationships within it, Social Science departments could be expected to be in turmoil and their members to agitate for change. It was this and not citizenship nor the nation in which they were trained which appears to account for the prominence of Social Scientists in the movement to reform university administration.

\section{Footnotes}

1. According to Burton R. Clark, "it is not until the 1960s that we discern a serious Sociology of higher education in the sense of a sub-field with a steady flow of writing. ." (B.R. Clark, 1973:5). The study of the organization of higher education and, more especially, of their internal government was described in 1963 as "an almost unexplored area in research on higher education" (Institute on College Self Study, 1963) with much of what passed as literature "largely reminiscent, anecdotal or hortatory" 


\section{The Role of the Department Head or Chairman}

(Anderson, 1963; cf. Olive, 1963:675). Awareness of these inadequacies, however, was but a first step toward correcting them and throughout the sixties, research on college and university administration attracted increasing attention (Baldridge, 1971). Interest in the department level had begun to appear by the end of the sixties (Dressel, et al., 1970; Brann, 1973).

2. The Report of the Commission devotes full chapters to each of the Board of Governors, the Senate and the President. Departmental Chairmen are considered along with Deans of Faculty and the primary emphasis is upon the Chairman's role in relating his department to the rest of the University. (see esp. Chapter 7, "Deans and Department Chairman, pp. 47-57.)

3. The view taken of Sociology by higher administrators may well be suggested by a memorandum from one Ontario President: "The key fact ... is that almost all Presidents regard the Department of Sociology in their institution as a special problem child. There are a few happy exceptions across the province, but most of us ... are wearied and disgusted by the problems which are regularly generated within the Department of Sociology. Trivial, tendentious and irresponsible theorizing, personal feuds carried to extreme lengths, with a total indifference to the reactions of colleagues and students, would seem to be the main manifestation of some fundamental malaise." Quoted in David Booth: "The Making of a Good Department: Structure and Process in Departmental Development," mimeo, The Department of Sociology and Anthropology, University of Windsor, 1975.

4. The four papers by Wendell Bell (Yale), LaMar T. Empey (Southern California), Gordon Hirabayashi (Alberta) and Thomas Ford Houtt (Arizona State), together with an introduction by Melvin L. DeFleur (Washington State) appeared subsequently in The Pacific Sociological Review 13:2 (Winter, 1970:5-18).

5. Since only the Faculty of Arts and Science was organized on a departmental basis, the focus of interest in the study, only the members of this faculty were surveyed. Each full-time appointee was invited by letter to participate and, if willingness was indicated, a questionnaire was sent. Not all department participated equally. The range is from a low of $50 \%$ (Hispanic) to $100 \%$ in the case of one department in each of the Social Sciences, Natural Sciences and Humanities (Economics, Bacteriology and Biochemistry, Slavonics). Generally, however, Social Science participation was highest (86.6\%), followed by Humanities $(71.6 \%$ ) and Natural Sciences $(69.7 \%)$.

6. The University of Victoria became fully autonomous only in 1963 , but it was built upon a predecessor college, Victoria College, with a record of distinguished undergraduate instruction. Beginning about 1956 the College began to expand rapidly until 1961, still in affiliation with the University of British Columbia, the first students to complete all their work at Victoria received their degrees. Rapid development continued thereafter through the sixties.

7. The three goups were composed of the following departments:

Social Science: Anthropology and Sociology, Economics, Geography, Political Science, Psychology. Natural Sciences: Bacteriology and Biochemistry, Biology, Chemistry, Mathematics, Physics.

Humanities: Classics, English, French Language and Literature, German Language and Literature, Hispanic and Italian Studies, History, Linguistics, Philosophy, Slavonic and Oriental Studies.

This grouping of respondents is undoubtedly arbitrary in some respects, and has the effect of weakening the influence of discipline, but it is considered necessary to protect the anonymity of respondents which might be lost if individual departments were reported.

8. Not only personal attributes of the members but the characteristics of the departments, such as their size, might also be involved. Controlling for discipline, however, there is no significant difference in the selection of role between small (15 or fewer) and medium-sized (16-30) Social Science departments. (There were no large Social Science departments.) In the Humanities also, size of department exercised no significant influence. In the Natural Science group, however, both the small and the large departments selected Leadership most frequently while in the medium sized, the Coordinator role was most chosen $(57.6 \%)$, with Leader next at $23.7 \%$ and Representative $15.2 \%$.

\section{Bibliography}

Ahman, J. Stanley (1963) "The Emerging Role of the Departmental Chairman: Be an Administrative Activist," in James Brann and Thomas A. Emmet (eds.), The Academic Department or Division Chairman: A Complex Role, Detroit: Belamp Publications, pp. 186-197. 
Anderson, G. Lester (1963) "The Organizational Character of American Colleges and Universities," in The Institute on College Self Study, The Study of Academic Administration, Boulder, Cal.; Western Interstate Commission for Higher Education, pp. 1-20.

Baldridge, J. Victor, ed., (1971) Academic Governance: Research on Institutional Politics and Decision Making, School of Education, Stanford University: McCutcheon Publications.

Barber, Bernard (1952) Science and the Social Order, Glencoe, Ill.: The Free Press.

Bell, Wendell (1970) "Three Trends Affecting the Role of Departmental Chairmen," The Pacific Sociological Review, 13(1): 6-10.

Blackburn, Robert T. and John D. Lindquist (1971) "Faculty Behavior in the Legislative Process: Professional Attitudes vs. Behavior Concerning Inclusion of Students in Academic DecisionMaking," Sociology of Education, 44:398-421.

Blackwell, Thomas Edward (1966) College and University Administration, New York Centre for Applied Research in Education.

Booth, David (1975) "The Making of a Good Department: Structure and Process in Departmental Development." Windsor, Department of Sociology and Anthropology, University of Windsor.

Brann, J. and Thomas A. Emmet, eds. (1963) The Academic Department or Division Chairman: A Complex Role, Detroit: Belamp Publications.

CAUT/AUCC (1966) University Government in Canada, Report of a Commission sponsored by the Canadian Association of University Teachers and the Association of Universities and Colleges of Canada. Toronto: University of Toronto Press.

Clark, Burton R. (1973) "Development of the Sociology of Higher Education," Sociology of Education, $46: 2-14$.

Clark, Samuel Delbert (1973) "The American Take Over of Canadian Sociology: Myth or Reality," The Dalhousie Review, 53(2): 205-218.

DeFleur, Melvin (1970) "The Chairmanship in a Changing Academic Setting: Sociology's Crisis in Leadership," The Pacific Sociological Review, 13(1): 5-6.

Dressel, Paul L., F. Craig Johnson and Philip M. Marcus (1970) The Confidence Crisis: An Analysis of University Departments, San Francisco: Jossey-Bass Inc.

Empey, LaMar T. (1970) "The Sociology of the Irreconcilable: The Chairman's Role," The Pacific Sociological Review, 13(1): 11-14.

Etzioni, Amatai (1964) Modern Organization. New York: Prentice-Hall.

Eustace, Rowland (1969) "The Government of Scholars," in David Martin, ed., Anarchy and Culture: The Problems of the Contemporary University.

Hirabayashi, Gordon (1970) “Departmental Chairman or Chore-Boy?" The Pacific Sociological Review, 13(1): 14-16.

Hoult, Thomas Ford (1970) "Many Are Called - Few Want to be Chosen," The Pacific Sociological Review, 13(1): 17-18.

Ladd, Everett Carll Jr. and Seymour Martin Lipset (1973) Professors, Unions, and American Higher Education, New York: Carnegie Commission on Higher Education.

Lambert, Ronald D. and James Curtis (1973) "Nationality and Professional Activity Correlates Among Social Scientists: Data Bearing on Conventional Wisdoms," Canadian Review of Sociology and Anthropology, 10(1): 62-80.

Lipset, Seymour Martin (1971) "Revolution and Counter Revolution: The United States and Canada," in W.E. Mann, Canada: A Sociological Profile, 2nd edition, Toronto: Copp Clark.

Mathews, Robin and James Steele (1971) The Struggle for Canadian Universities, Toronto: Free Press.

Olive, Betsy Ann (1967) "The Administration of Higher Education: A Bibliographical Survey," Administrative Science Quarterly, II(4): 671-677.

Parsons, Talcott and Gerald M. Platt (1967) "Considerations on the American Academic System," Minerva, 6(4): 495-523.

Rourke, Francis E. and Glenn E. Brooks (1966) The Managerial Revolution and Higher Education, Baltimore: John Hopkins Press.

Spaulding, Charles B. and Henry A. Turner (1968) "Political Orientation and Field of Specialization Among College Professors," Sociology of Education, 41(3): 247-262.

Symons, T.H.B. (1975) To Know Ourselves: The Report of the Commission on Canadian Studies, 2 vols., Ottawa, The Association of Universities and Colleges in Canada. 